ISSN: 2236-269X

DOI: 10.14807/ijmp.v10i4.1000

\title{
URBAN MOBILITY: SERVICE LEVEL AND DEMAND FORECAST STUDY ON A ROAD IN THE CITY OF SÃO PAULO
}

\author{
Alcir das Neves Gomes \\ Instituto Federal de Educação, Ciência e tecnologia de São \\ Paulo, Campus Suzano; FATEC Zona Sul, Brazil \\ E-mail: alcir.gomes@ifsp.edu.br \\ Elson Araújo \\ Instituto Federal de São Paulo, Campus- Suzano, Brazil \\ E-mail: earaujo775@gmail.com \\ Osmar Martins Souza \\ Instituto Federal de São Paulo, Campus- Suzano, Brazil \\ E-mail: osmoz800@hotmail.com \\ Wagner Roberto Garo Júnior \\ Instituto Federal de São Paulo, Campus- Suzano, Brazil \\ E-mail: wagner.garo@ifsp.edu.br \\ Submission: 01/31/2019 \\ Accept: 02/10/2019
}

\section{ABSTRACT}

The theme urban mobility has been gaining prominence in recent times due to the impact it causes on the quality of life of people living in large centers, this article aims to study and evaluate the Capacity and Level of Service in a specific route in the city of São Paulo based on the concepts and methods established in Highway Capacity Manual 2000 (HCM 2000), in addition to using linear regression to estimate the forecast of short-term traffic demand in a biennial scenario, to propose alternatives to provide a satisfactory Service Level compatible with the forecast demand, to analyze the efficiency of the method as a tool in the decision-making process in the measures for the improvement of circulation and retardation in the municipal road system. In this exploratory, quantitative and descriptive study, the calculations were performed using concepts and methods contained in HCM 2000 evaluating the efficiency of the method as a means of obtaining information to support decision-making regarding the improvement of urban mobility. The results showed a tendency to reduce the volume of vehicle flow in the studied road. 
The results obtained demonstrate that the tools applied in the present work can be of great value for decision making or proposition measures for improvements in the attendance of demand in the capacity of the roads to provide a Service Level that allows to improve the satisfaction of the users of the road system of the municipality of São Paulo.

Keywords: urban mobility, Service Level, demand forecasting, decision making

\title{
1. INTRODUCTION
}

Urban mobility is fundamental in characterizing the quality of life of a society as well as in the degree of economic and social development, disordered urban growth due to occupation and land use, excessive increase in car use, lack of infrastructure, pollution of the environment, among other factors, directly interfere with the quality of life of the population. These factors have influenced researchers, managers and decision makers to seek new ways of discussing and finding solutions to these urban issues (MAGAGNIN; SILVA, 2008).

Thus, Ferronatto (2002) explains:

\begin{abstract}
The demand for travel is derived from the activities of people: activities of production and consumption of goods. The greater the development of society, the greater the economic activity and, consequently, the need for displacements. The current pattern of urban land use in large cities, where disorderly horizontal growth and specialization of the different residential, commercial and industrial zones takes place, leads to the need for motorized transportation to cover the great distances that separate people from most their destinations (FERRONATTO, 2002, p.1).
\end{abstract}

However, the imbalance between the pace of initiatives to improve urban mobility and the growing problems in large cities (increased travel times, air pollution and traffic accidents) has contributed to the deterioration of urban living conditions regardless of income improvement of work and greater access to durable goods by the poorest part of the population (GOMIDE; GALINDO, 2013).

The management of the demand for transportation aims to manage times of greater concentration of vehicles (peak times). These measures are frequently applied in large urban centers and include traffic management, such as restrictions on the access of cars to certain areas and the collection of fees for the use of roads, in some cases differentiated by time of day. In addition to the temporal and spatial redistribution of traffic, these measures aim to transfer part of the demand for public transportation (FERRONATTO, 2002). 
The objective of this work is to measure and evaluate the road capacity and the Service Level in a specific route in the city of São Paulo using the concepts and methods established in Highway Capacity Manual 2000 (HCM2000) (SETTI, 2002), which can be translated as a Road Capacity Manual, the mathematical model of linear regression was also used to calculate the traffic demand forecast to propose alternatives to provide a Service Level compatible with expected demand, between levels $C$ and $D$, also analyze its efficiency as an alternative method in the decisionmaking process in the measures of improvement of circulation and retardation in the municipal road system.

The specific objectives are to propose solutions for the current situation and the projected demand.

For the development of this article, a theoretical review is presented containing some relevant elements for the proposed application including the discussion of the concept of urban mobility, the presentation of $\mathrm{HCM}$ methodology for calculation and analysis of the capacity and level of service of highways, the forecasting tool of demand by means of mathematical models for the circulation of vehicles, and basic aspects of the evaluation techniques employed. The third part deals with the methodology and development of the research followed by the analysis of results and finalizing the final discussions about the results of the study.

\section{THEORETICAL REVIEW}

Cities are considered dynamic organisms, with remarkable transformations over time, including their spatial structure, and transport becomes a key element in these transformations. Transport systems are strongly linked to the growth and development of cities with a role in the organization and structuring of urban space (KNEIB; DA SILVA; PORTUGAL, 2004).

Mobility is by definition a feature related to the movements carried out by individuals in their various activities, such as study, work, leisure and others. In this context, cities play an important role in the innumerable relations of exchange of goods and services, culture and knowledge among its inhabitants, but this possibility is only achieved if there are adequate conditions of mobility for the people (MINISTÉRIO DAS CIDADES, 2006 apud MAGAGNIN; SILVA, 2008). 
A great example of this is the development and growth of the metropolis of São Paulo and the problems generated by urban mobility and its transportation system.

According to Scaringella (2001), "the best understanding of the São Paulo urban mobility crisis is a more detailed analysis of the various relationships between: urban land use and occupation, transportation systems and road infrastructure, and the interaction between human factor, vehicle, public road and environment ".

One of the aggravating factors that most impacted on the issue of urban mobility is related to the vertiginous growth of individual vehicles in circulation in most of the Brazilian metropolises, especially in São Paulo, with the largest vehicle fleet in Brazil.

Thus, Gomide and Galindo (2013) show data for that growth:

Based on data from Denatran and IBGE, there is a growth of the fleet of cars and motorcycles from 1998 to 2012 at a rate ten times higher than the population growth. As a result, the motorization rate more than doubled in that period (slightly more than twice for cars and 2.5 times for total cars and motorcycles), moving to a ratio of 0.2 bikes for every 10 inhabitants for 1 bike / inhabitant and $1.2 \mathrm{car} / 10$ inhabitants to 2.6 (GOMIDE and GALINDO, 2013, p.37).

For this reason, the Traffic Engineering Company (CET) of the city of São Paulo conducts a systematic study to monitor fluidity by means of classified volumetric counting and delayed travel time, in the main roads of the city, since 1977, providing data for society and using them to take measures to improve urban mobility (CET, 2018).

The purpose of monitoring the volume of vehicles that use a given route is to obtain data to obtain the true notion of the demand of the users of the road system of the city of São Paulo and that the demand is related to the behavior of the people.

According to the Highway Capacity Manual (HCM) there is a distinction between demand and volume. Demand is the amount of vehicles you want to use for a stretch of track while volume is the discharge rate of a track stretch. If there is no congestion (or row), demand equals volume (TRB, 2000, apud SETTI, 2009).

Quality of service is the mode used by traffic engineers to evaluate the "quality" of the trip perceived by road users. This concept of quality of service, initially proposed in the USA, is an essential measure to evaluate the performance of road segments from the point of view of traffic flow. The HCM is the basic reference for the evaluation of the quality of service that defined the parameters used to measure the quality of 
service and a set of established procedures to systematize and standardize this measurement (SETTI, 2009).

The publication of the first edition of the Highway Capacity Manual (HCM) occurred in 1950 as a result of a joint work of the Highway Research Board Road Capacity Committee, which became the basic reference for the study of the capacity and the Level of Service of system components of road transport with wide acceptance worldwide (SETTI, 2002).

The analysis of the capacity of a road component consists of elaborating a set of models or analytical equations that relate the flow levels, the geometry, the environmental conditions and the strategies of control as well as the measures of the quality of service. Thus, these models and equations make it possible to determine the maximum capacity of transport-transport of an infrastructure and the Service Level in different degrees of flow (HOEL; GARBER; SADEK, 2011).

According to Setti (2002), the main purpose of a capacity analysis is to measure the maximum flow rate of vehicles that a stretch of highway can withstand under preestablished operating conditions through the application of clearly defined methods.

The concept of Service Level is closely associated with the concept of capacity because it is a direct function of the level of utilization of the infrastructure. As the flow level increases, the quality of service clearly deteriorates (HOEL; GARBER; SADEK, 2011).

The Service Level is a quality measure that requires the application of quantitative measures to determine the characteristics of the operating conditions in the traffic flow and can be evaluated by means of measures of performance that cover the speed and time of travel, the ease of maneuvering, traffic interruptions as well as comfort and convenience (SETTI, 2002).

The density depicts the proximity between vehicles in the flow stream and reveals the ease of performing maneuvers within the flow as well as the level of psychological comfort of the users. It is also the measure of performance adopted for basic segments of freeways and dual lane highways and the lower the density, the better the quality of service; the higher the density, the worse the quality of service (SETTI, 2002).

According to Setti (2002), the HCM 2000 establishes six levels of service, identified by letters that vary from $A$ to $F$, with $A$ being the best Service Level and $F$ the worst. Table 1 presents the criteria established by the HCM 2000 for the definition of service levels: 
DOI: 10.14807/ijmp.v10i4.1000

Table 1: Criteria for establishing service levels

\begin{tabular}{|c|c|}
\hline Service level & Density [vehicle / (km.lane)] \\
\hline A & $0<k \leq 7$ \\
\hline B & $7<k \leq 11$ \\
\hline C & $11<k \leq 16$ \\
\hline D & $16<k \leq 22$ \\
\hline E & $22<k \leq 28$ \\
\hline F & $28<k$ \\
\hline \multicolumn{2}{|c|}{ Source: SETTI, $(2002)$} \\
\hline
\end{tabular}

The HCM 2000 stipulates four types of application for the analysis of capacity and Level of Service of highways denominating type I to type IV analyzes, for the present study will be used the type I and IV.

The type I analyzes answer questions such as What is the Service Level of the highway?. Using the input measurements the hourly flow rate - Vp and the free - flow velocity - FFS, resulting in the D - density that allows determining the Service level (SETTI, 2002).

Type IV analyzes generate the number of $\mathrm{N}$ ranges that provide a desired Service Level, from the Vp flow rate and the free flow rate FFS. They are used for roadway design to define the number of lanes required to support the annual average daily flow obtained by traffic estimates (SETTI, 2002).

The concept of demand forecasting may be associated with projection, or even extrapolation of past trends (BOLAND, 1985 apud VERRUCK; BAMPI; MILAN, 2009). According Makridakis (1988 apud VERRUCK; BAMPI; MILAN, 2009) the demand forecast helps in the strategic decisions of the company, its planning or any attitude that considers future events.

With regard to the methodology of demand forecasting, it can be qualitative or quantitative. The quantitative methods are based on mathematical models, based on statistics, as a way to carry out the forecast (MOREIRA, 2004). In general, they are more used in short-term scenarios, since it is not possible to predict by these techniques changes in the scenario (FLEURY; WANKE; FIGUEIREDO, 2003).

Thus, Ferronatto (2002) states that the demand for transport is not only determined by the price, as well as the demand for any goods or services. The quantity demanded is also affected by the characteristics of the service, and those of competing modes (car, train, etc.), as well as other factors. 
The public policy interest in a more homogeneous distribution of travel demand results from the losses caused by congestion (in energy consumption, time spent on transport and environmental quality) and the waste of resources that corresponds to the idle capacity of collective transportation (in terms of equipment and work) and of the urban road system in times of low demand (FERRONATTO, 2002).

\begin{abstract}
Modeling in transport tries to predict future demands through mathematical, computational, behavioral and other resources. In this way, the analysis of transport problems began to be based on a theoretical basis, through the use of models that aim to represent the characteristics of a new reality. Demand modeling strategies and transport system offerings have become essential in the decision-making process and planning of this system (LEMES, 2005, p.14).
\end{abstract}

According to Lopes (2005) to determine the forecast of the transport demand, it is necessary to carry out a detailed survey of the current conditions. The city is divided into traffic zones and from there the traffic between each pair of zones is determined. The result is a table of origins and destinations (O-D Matrix), with an intimate relationship with the attraction and production of trips.

Already Ferreira (1999 cited MENDONCA, 2008) thus states: "the analysis of this demand is a process that seeks to identify the determinants of demand and how they interact and affect the evolution of the traffic volume (or travel)".

The development of the transport demand analysis process is carried out using statistical and mathematical models. According to Novaes (1986 apud MENDONÇA, 2008):

These transport demand analysis models can be used for short-term forecasts with current, medium- and long-term forecasts with detailed projections of socioeconomic variables and, in the long term, involving regional planning and land use planning (NOVAES, 1986 apud MENDONÇA, 2008, p.18).

By means of demand forecasting models, a future scenario of land use and occupation and the demand for transport can be reproduced in which it is possible to predict the socio-economic growth of the city, the future demand behavior in the road system, to locate routes with a saturated capacity, to propose modifications in the route of the vehicles and / or in the physical road network, and even to verify the effectiveness of the planning by means of dynamic simulation of the future flows allocated in the road system, using specific programs (LEMES, 2005). 
According to Molinero and Arellano (1998 apud MENDONÇA, 2008), there is the possibility of developing models for forecasting urban passenger transport demand using two methods:

- plan demand in proportion to the evolution of population growth or to the increase in individual mobility.

- plan demand by comparing with other cities where living standards and mobility are similar or slightly larger

\section{METHODOLOGY}

The present article takes the form of an exploratory research, according to Gil (2002), the exploratory research is flexible and can take the form of bibliographic research. In order to study the Service Level of a specific route in the city of São Paulo, the volume monitoring data from the Mobility Monitoring Survey of the CET (2018) was used to evaluate capacity and Type of Service Level I and IV, according to the methodology proposed by HCM 2000 , of a specific point of the route chosen for the study.

The route chosen is the "ROTA 01G" which includes the following routes: Eusébio Matoso Avenue, Rebouças Avenue and Consolação Street, based on data provided by the CET database of the said city and that route was established point 3 as object of study in the afternoon towards the center to the neighborhood.

The objective of the volumetric counting survey conducted by CET is to determine the quantity, composition and direction of the flow of vehicles in a section of the road system per unit time. The number of vehicles is raised by researchers using manual counters. The researcher is positioned in the counting section, in a location with good visibility of the flow to be observed. The number of researchers is scaled for each point, depending on the number of bands, volume and composition of traffic.

The number of vehicles is counted in three or four points of the route. One of the counting points is defined as the main one. At this point, counting is performed for two days. Traffic flow counting is directional, always done in both directions of the road, when it is two-way. The senses are named predominantly as neighborhood to the center and center to the neighborhood. 
With the result of the Type I Service Level obtained from the counts, the study was performed using the Service Level type IV method, as stipulated by HCM 2000, to define the current need to conduct the flow satisfactorily with a Service Level $C$ or $\mathrm{D}$ and then a demand forecast was made in the vehicle circulation volume using mathematical models such as the Least Squares Method (LSM) and again an analysis to define a project proposal to meet future needs with Level of Service C or D to demonstrate how the method can meet the needs in decision making or measures for improvements in the flow of vehicles.

\section{ANALYSIS OF RESULTS AND DISCUSSION}

As mentioned in the methodology, a specific route was used as object of study as illustrated in figure 1 :

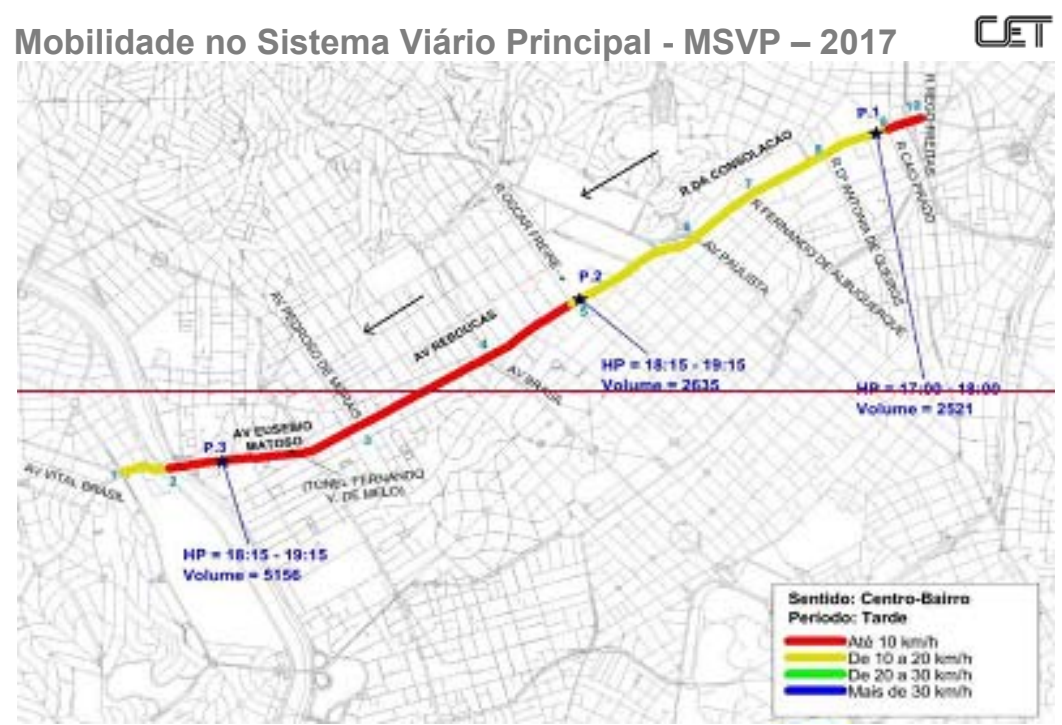

Figure 1: Route used as object of study

Source: CET (2018)

According to HCM 2000 (SETTI, 2002), determination of the Type I Service Level of a track segment involves three parameters: flow rate, free-flow velocity and density.

For the definition of the flow rate the following formulas are used:

Equation 1: Flow Rate Formula

$\mathrm{V}_{\mathrm{p}}=\frac{\mathrm{Q}}{\mathrm{PHV} \times \mathrm{N} \times \mathrm{f}_{\mathrm{HV}} \times \mathrm{f}_{\mathrm{p}}}$ 
DOI: 10.14807/ijmp.v10i4.1000

- $V_{p}$ : passenger-car equivalent flow rate (pce/h.lane);

- $Q$ : demand volume for full peak hour (veh/h);

- PHV: peak-hour factor;

- $\quad N$ : number of traffic lanes;

- $f_{L W}$ : adjustment factor for heavy vehicles; and

- $f_{p}$ : adjustment factor for driver type.

Equation 2: Adjustment factor formula for heavy vehicles

$$
f_{\text {HV }}=\frac{1}{1+\mathrm{P}_{\mathrm{T}} \times\left(\mathrm{E}_{\mathrm{T}}-1\right)+\mathrm{P}_{\mathrm{R}} \times\left(\mathrm{E}_{\mathrm{R}}-1\right)}
$$

- $f_{t w}$ : adjustment factor for heavy vehicles;

- $P_{T}$ : percentage of trucks and buses in the traffic flow;

- $E_{T}$ : equivalence factor for trucks and buses;

- $\mu_{R}$ : percentage of recreational vehicles; and

- $E_{R}$ : equivalence factor for recreational vehicles.

To define the free flow speed the following formula:

Equation 3: Free-flow speed formula

$$
\mathrm{FFS}=\mathrm{FFS}_{1}-\mathrm{f}_{\mathrm{LW}}-\mathrm{f}_{\mathrm{LC}}-\mathrm{f}_{\mathrm{N}}-\mathrm{f}_{\mathrm{ID}}
$$

- FFS: free-flow speed $[\mathrm{km} / \mathrm{h}]$;

- FFS: free-flow speed in the analysis direction $[\mathrm{Km} / \mathrm{h}]$;

- $f_{L W}:$ adjustment for lane width $[\mathrm{km} / \mathrm{h}]$;

- $f_{L e}:$ adjustment for lateral width $[\mathrm{km} / \mathrm{h}]$; 
- $f_{N}$ : adjustment for number of lanes $[\mathrm{km} / \mathrm{h}]$; and

- $f_{L D}$ : adjustment for interchange density $[\mathrm{km} / \mathrm{h}]$.

And finally, the density:

$\mathrm{D}=\frac{\mathrm{Vp}}{\text { IFS }}$

Therefore, based on the data provided by the CET database in which:

- Q equals 5156 vehicles;

- PHF equal to 0.98;

- $\quad \mathrm{N}$ equal to 3 lanes of 3 meters wide each;

- Pt equal to $4 \%$ and Pr equal to $0 \%$.

Using the adjustment and equivalence factors established by the $\mathrm{HCM}$, and applying them in the formulas previously demonstrated, the results obtained were:

$$
\begin{aligned}
& f_{U V}=\frac{1}{1+0,04 \times(1,5-1)+0 \times(1,2-1)}=0,98 \\
& V_{p}=\frac{5156}{0,98 \times 3 \times 0,98 \times 1}=1789,53[\mathrm{cp} / \text { (h.lane) }]
\end{aligned}
$$

For the purpose of calculation, FFS was defined according to figure 2 of the SETTI (2009) study in which the regulated speed of the route is used as free flow velocity. Therefore, the maximum permitted speed of the stretch of track under study is regulated at $50 \mathrm{~km} / \mathrm{h}$. Applying the data in the density formula gives the following result:

$\mathrm{D}=\frac{1789,53}{50}=35,79 \cong 36$ veic $/(\mathrm{km}$ lane $)$

From the result of the density it was verified that the route is operating at Service Level $\mathrm{F}$, that is, the flow rate is greater than the capacity that the route entails. In order to perform a Type IV Service Level analysis, Table 2 was elaborated with the various possibilities for reaching Service Levels $C$ and $D$ by applying the formulas already presented in previous calculations: 
DOI: 10.14807/ijmp.v10i4.1000

Table 2: Type IV Service Level Analysis

\begin{tabular}{|c|c|c|c|}
\hline Number of lanes & Width of lanes (m) & $\begin{array}{c}\text { Density } \\
\text { [pce/(Km.lane)] }\end{array}$ & Service level \\
\hline 4 & 3,0 & 27 & $\mathrm{E}$ \\
\hline 5 & 3,0 & 22 & $\mathrm{D}$ \\
\hline 6 & 3,0 & 18 & $\mathrm{D}$ \\
\hline 7 & 3,0 & 16 & $\mathrm{C}$ \\
\hline
\end{tabular}

Source: Prepared by Authors

It is noteworthy, analyzing the data obtained in Table 2, that in order to provide Service Level D in which, according to the HCM, the density varies from 16 to 22 vehicles per $\mathrm{Km}$ of track, there is a need to extend the track for at least 5 bearing ranges of $3.0 \mathrm{~m}$ wide each, but in this case the solution is much of the maximum flow of this Service Level, which suggests the need to work with 6 bearing ranges Already to provide a Service Level $C$ in which, according to the HCM, the density varies from 11 to 16 vehicles per km of track would only be possible with a widening of the track to 7 lanes of $3.0 \mathrm{~m}$ wide each bearing. The urban characteristics of the studied section do not allow the process of change to occur in the short term, making feasible the study of demand forecast by the proposed method, as seen in the literature review.

Thus historical data from previous years of vehicle traffic counting at the peak time of the route shown in figure 1 were used as the basis of the calculations made for the prediction of vehicle traffic demand at point 3 of the given route using the mathematical model (LSM), as shown in Table 3:

Table 3: Base data and the forecast of demand for the next period

\begin{tabular}{|c|c|c|c|c|c|c|}
\hline & 2009 & 2011 & 2013 & 2015 & 2017 & 2019 \\
\hline Peak Hour Volume & 6204 & 6391 & 6004 & 4521 & 5156 & 4465 \\
\hline
\end{tabular}

The linear regression calculations carried out resulted in a tendency to reduce vehicle traffic volume at the peak time at point 3 of the route used as the object of study, as can be seen by means of the negative angular coefficient, that is, $b=-198.3$ and a correlation considered strong and negative since it presents a coefficient $r=$ 0.793 which reinforces the reliability of the data.

For the demand foreseen in table 3, the Type IV Service Level analysis is presented in Table 4 below: 
DOI: 10.14807/ijmp.v10i4.1000

Table 4: Type IV Service Level Analysis for expected demand

\begin{tabular}{|c|c|c|c|}
\hline Number of lanes & Width of lanes (m) & $\begin{array}{c}\text { Density } \\
\text { [pce/(Km.lane)] }\end{array}$ & Service level \\
\hline 3 & 3,0 & 31 & $\mathrm{~F}$ \\
\hline 4 & 3,0 & 23 & $\mathrm{E}$ \\
\hline 5 & 3,0 & 19 & $\mathrm{D}$ \\
\hline 6 & 3,0 & 16 & $\mathrm{C}$ \\
\hline
\end{tabular}

Source: Prepared by Authors

Analyzing the results presented in Table 4, it can be observed that with the trend of reduction in the flow volume of the track in the peak time, as obtained by the forecast of demand for 2019 , with 4 lanes of $3.0 \mathrm{~m}$ wide bearing, almost reached the density value for the provision of Service Level $D$ that would be 22 vehicles per $\mathrm{km}$ of track; which is already possible with the widening of the track to 5 lanes of $3.0 \mathrm{~m}$ wide each bearing a density of 19 vehicles per $\mathrm{km}$ of track being considered an acceptable Service Level and of good quality in the perception of the users mainly if the volume of vehicle circulation in the studied road maintain its downward trend. The possibility of the provision of a Service Level $\mathrm{C}$ becomes possible if the track is enlarged to 6 lanes of $3.0 \mathrm{~m}$ wide, which is twice the number of lanes that are currently available and what has not occurred in the previous analysis with the demand verified in the year 2017.

The suggested increase in capacity is difficult to achieve due to the type of land occupation in the region that would require a long-term project and high investments. However, traffic engineering solutions, such as Reversible Bands at a certain time / track direction, adding one or two bearing ranges in the opposite direction, or diverting part of the flow to parallel paths, thereby improving the Service Level would be options for solve the problem, remembering that the opposite flow must be considered so that there is no overhead of the system.

\section{CONCLUSIONS}

The city of São Paulo suffers from the growth of the flow of private motor vehicles. Not to mention the fact that its main means of public transport (the bus, despite its equivalence factor, can transit through exclusive lanes, not always shared with private motor vehicles) also uses the main road system to operate.

The study carried out using the methods established by HCM (2000) has shown to be efficient for the understanding of the current situation regarding urban mobility in a certain stretch of road or route of the São Paulo city road system and in relation to 
the capacity and the Level of Service of the same. Applying linear regression using the LSM mathematical model, short-term future requirements can be projected with respect to the capacity of the road to support the demand and quality of service to be made available to users, as observed by Fleury, Wanke and Figueiredo (2003), forecasting models cannot support long-term decisions because they cannot predict scenario changes.

However, for the short-term analysis, there was a tendency to reduce the flow volume of vehicles on the road, which suggests changes in the behavior of the users who use the road to make their mobility in the municipality. The development of the work has shown that the applied tools can be of great value for decision making or measures for improvements in the service demand in the capacity of the roads to enable a Service Level with satisfactory quality in the perception of the users of the road system of the São Paulo in the short term.

In the last few years, many technologies have been used to obtain data, with city-wide equipment and detection sensors, not to mention mobile phones, which enable real-time information of all kinds through applications.

For this reason, it is possible to suggest future studies on how the use of shared car applications, shared bicycles, collective transportation (bus, train and subway) can contribute to the optimization of the route traveled (time / distance). The dynamics of traffic demand growth is complex, creating the possibility of associating traffic engineering with scientific research and technological innovations, to create tools to improve the fluidity of the road system to meet the displacement needs of society.

\section{REFERENCES}

BOLAND, J. J. (1985) Forecasting water use: a tutorial. Computer Applications in water Resources. New York: H. C. Torno.

CET (2018) Pesquisa de Monitoração da Mobilidade. Mobilidade no Sistema Viário Principal. Available in: http://www.cetsp.com.br/media/499255/2015.pdf. Access: August 25, 2018.

FERREIRA, E. A. (1999) Um Método de Utilização de Dados de Pesquisa Embarque/Desembarque na Calibração de Modelos de Distribuição do Tipo Gravitacional. Master Dissertation, School of Engineering of São Carlos of the University of São Paulo. São Carlos.

FERRONATTO, L. G. (2002) Potencial de medidas de gerenciamento da demanda no transporte público urbano por ônibus. Dissertation (Master in 
INDEPENDENT JOURNAL OF MANAGEMENT \& PRODUCTION (IJM\&P)

http://www.ijmp.jor.br

v. 10, n. 4, Special Edition IFLOG 2018

ISSN: 2236-269X

DOI: $10.14807 /$ ijmp.v10i4.1000

Production Engineering), School of Engineering, Federal University of Rio Grande do Sul. Available at: http://www.lume.ufrgs.br/handle/10183/1964 Access: June 2, 2017.

FLEURY, P. F.; WANKE, P.; FIGUEIREDO, K. F. (2003) Logística e gerenciamento da cadeia de suprimentos: planejamento do fluxo de produtos e dos recursos. São Paulo: Atlas.

GIL, A. C. (2002) Como elaborar projetos de pesquisa. $4^{a}$ edição, São Paulo, Atlas.

GOMIDE, A. D. Á.; GALINDO, E. P. (2013) A mobilidade urbana: uma agenda inconclusa ou o retorno daquilo que não foi. Estudos Avançados, v. 27, n. 79, p. 27-39. Available in: https://doi.org/10.1590/S0103-40142013000300003 Access: June 2, 2017.

HOEL, L. A.; GARBER, N. J.; SADEK, A. W. (2011) Engenharia de infraestrutura de transportes. São Paulo: Cengage Learning.

KNEIB, E. C.; DA SILVA, P. C. M.; DA SILVA PORTUGAL, L. (2010) Impactos decorrentes da implantação de pólos geradores de viagens na estrutura espacial das cidades. Transportes, v. 18, n. 1. Available in:

https://www.revistatransportes.org.br/anpet/article/view/381 Access: June 2, 2017.

LEMES, D. C. S. S. (2005) Geração e análises do cenário futuro como um instrumento do planejamento urbano e de transportes. Dissertation (Master degree), Federal University of Uberlândia. Available in:

http://www.webposgrad.propp.ufu.br/ppg/producao_anexos/009_Daniela\%20Cristina \%20Santos\%20Simamoto\%20Lemes.pdf. Access: June 10, $20 \overline{17}$.

LOPES, S. B. (2005) Efeitos da dependência espacial em modelos de previsão de demanda por transporte. Doctoral thesis. University of Sao Paulo. Available in: http://www.teses.usp.br/teses/disponiveis/18/18137/tde-12042005-

111306/en.php. Access: June 10, 2017.

MAGAGNIN, R. C.; DA SILVA, A. N. R. (2008) A percepção do especialista sobre o tema mobilidade urbana. Transportes, v. 16, n. 1. Available in: http://dx.doi.org/10.14295/transportes.v16i1.13. Access: June 2, 2017.

MAKRIDAKIS, S. (1988) Metaforecasting: ways of improving forecasting accuracy and usefulness. International Journal of Forecasting, v. 4, p. 467-491.

MINISTÉRIO DAS CIDADES (2006). Curso Gestão Integrada da Mobilidade Urbana. Módulo I: Política Nacional de Mobilidade Urbana. Ministry of Cities, National Program for Capacity Building of Cities, Brasília. Available in: http://www.cidades.gov.br/CursoSemob/modulos.html

MENDONÇA, A. C. (2008) Desenvolvimento de um modelo de previsão da demanda de passageiros do transporte rodoviário interestadual utilizando regressão com efeitos espaciais locais. Master Dissertation, Publication T.DM014A / 2008, Department of Civil and Environmental Engineering, Faculty of Technology, University of Brasília, DF. Available in: http://repositorio.unb.br/handle/10482/3747. Access: June 10, 2017.

MOLINERO, A. M.; ARELLANO, I. S. (1998) Transporte Público: Planeácion, Diseño, Operación y Administración. $3^{a}$ Ed., Colônia Nápoles, México.

MOREIRA, D. A. (2004) Administração da produção e operações. São Paulo: 
Pioneira Thomson Learning.

NOVAES, A. G. (1986) Sistemas de Transportes Volume I: Análise de Demanda. São Paulo: Ed. Edgard Blücher.

SETTI, J. R. A. (2002) Tecnologia de Transportes. São Paulo: EESC-USP.

SETTI, J. R. A. (2009) Highway Capacity Manual ou um manual de capacidade rodoviária brasileiro. In: Annals of the Brazilian Congress of Highways \& Concessions 2009. Available in:

http://www.stt.eesc.usp.br/setti/papers/cbr2009/setti2009.pdf. Access: August 4, 2018.

SCARINGELLA, R. S. (2001) A crise da mobilidade urbana em São Paulo. São Paulo em perspectiva, v. 15, n. 1, p. 55-59. Available in: https://dx.doi.org/ 10.1590/S0102-88392001000100007. Access: June 2, 2017.

TRB (2000) Highway Capacity Manual 2000. Transportation Research Board, Washington, D.C.

VERRUCK, F.; BAMPI, R. E.; MILAN, G. S. (2009) Previsão de Demanda em Operações de Serviços: Um Estudo em uma Empresa do Setor de Transportes. Symposium on Production, Logistics and International Operations Administration -XII SIMPOI. São Paulo. 